\title{
LATE SPRING FREEZES IN POLAND IN RELATION TO ATMOSPHERIC CIRCULATION
}

\author{
Zbigniew Ustrnul ${ }^{1}$, AgnieszKa Wypych ${ }^{1}$, Julie A. Winkler², Danuta CZekierda ${ }^{3}$ \\ ${ }^{1}$ Institute of Geography and Spatial Management, Jagiellonian University in Krakow, Poland \\ ${ }^{2}$ Department of Geography, Michigan State University, East Lansing, USA \\ ${ }^{3}$ Institute of Meteorology and Water Management - National Research Institute, Kraków, Poland
}

Manuscript received: June 2, 2014

Revised version: August 1, 2014

\begin{abstract}
Ustrnul Z., WyPych A., WinKLER J.A., CZEKIERDA D., 2014. Late spring freezes in Poland in relation to atmospheric circulation. Quaestiones Geographicae 33(3), Bogucki Wydawnictwo Naukowe, Poznań, pp. 165-172, 1 table, 5 figs. DOI 10.2478/quageo-2014-0039, ISSN 0137-477X.

AвSTRACT: Late spring freeze events, a significant agroclimatic hazard, are investigated for Poland. Daily minimum air temperatures from 184 stations for the period 1951-2010 were used to analyze the frequency and conditional probability of late spring freezes. In addition, three classification schemes were employed to investigate the atmospheric circulation responsible for late spring freezes events. The findings suggest that knowledge of the airflow influencing late spring freezes can help to understand the complex historical trends and projected future changes in freeze risk for perennial crops.
\end{abstract}

KEY WORDS: freeze, late spring, agroclimate, atmospheric circulation, Poland

Address of the corresponding author: Zbigniew Ustrnul, Institute of Geography and Spatial Management, Jagiellonian University in Krakow, Gronostajowa 7, 30-387 Kraków, Polska; e-mail: zbigniew.ustrnul@uj.edu.pl

\section{Introduction}

Atmospheric circulation is crucial in shaping climatic and weather conditions. Therefore, the relationships between large-scale circulation and local and regional weather and climate, including the occurrence of extreme phenomena and events, are the subject of many papers (e.g. Yarnal 1993, Buishand, Brandsma 1997, Niedźwiedź 2000, Wibig 2001, Huth et al. 2008, Ustrnul, Czekierda 2009, Moore, Renfrew 2012). The relationship between circulation and regional weather and climate was also a focus of the COST733 Action program (Beck, Philip 2010).

Atmospheric circulation plays an important role in the spatial variation of air temperature (e.g. Ustrnul et al. 2010), which in turn has a large impact on numerous environmental processes. Unquestionable is the effect that air temperature has on vegetation. Consequently, thermal variations (i.e., inter-annual fluctuations, day-to-day variability, temperature extremes) impact the agricultural potential of a given area (e.g. Żmudzka 2004). Perennial crops (e.g. fruit trees) are particularly sensitive to fluctuating temperatures. Most damage to perennial fruit trees in midlatitude locations occurs during spring bloom when below-freezing temperatures may harm flower buds following the loss of cold hardiness. Severe damage may also occur during winter both as a result of too low (below the points of resilience) temperature and a consequence of long-lasting thaws, which boost life processes and can be followed by tissue-destructive cold temperatures. 
Temperature damage to different plant species (especially fruit trees) is widely discussed by agricultural meteorologists and bioclimatologists (e.g. Rigby, Porporato 2008, Kreyling et al. 2012), and a summary of climate impacts on perennial crops can be found in Winkler et al. (2013a).

Several studies have shown that the vegetative season lengthens by approximately 5 days per $1^{\circ} \mathrm{C}$ increase in annual mean temperature (Chmielewski, Rötzer 2001). A significant temperature rise in early spring (February-April) results in earlier plant growth, and for fruit trees an earlier loss of cold hardiness by flower buds (Chmielewski, Rötzer 2001, Chmielewski et al. 2004) and consequently potentially greater risk to late spring freezes (Chmielewski et al. 2004). However, recent trends in the risk of spring freeze damage are complex. While some analyses, such as that by Scheifinger et al. (2003) for Germany, Austria and Switzerland suggest that the last date of spring freeze has moved forward in time in synchrony with plant development, analyses of apple production in Finland (Kaukoranta et al. 2010), and apple, pear, peach, apricot, sweet cherry, plum, and grape production in eastern Canada (Rochette et al. 2004) suggest that the risk of freeze damage has increased with warmer temperatures. Not surprisingly, considerable uncertainty also exists regarding the future susceptibility of perennial crops to springtime freeze damage. For example, the climate projections employed by Eccel et al. (2009) to estimate future freeze risk for apple production in Italy suggested a slight reduction in freeze risk, whereas the findings by Winkler et al. (2013b) for sour cherry production in the North American Great Lakes region are more uncertain. Utilizing a large ensemble of future climate projections, they found that close to 40 percent of the scenarios projected little change in plant development at the time of last spring freeze, and, of the remaining scenarios, the number suggesting delayed crop development at last spring freeze was equal to the number suggesting greater crop development.

The relationship between atmospheric circulation and late spring freeze potentially provides an alternative approach for investigating past and future trends in spring freeze risk for perennial crops, under the assumption that only a small number of airflow patterns are responsible for late spring freeze events and that changes in the frequency of these airflow patterns will result in changes in the risk of freeze damage. This study represents a preliminary analysis of the observed relationship between airflow patterns and late spring freeze events. The study focuses on spring freeze risk in Poland, an area where perennial crops are an increasingly important component of the agricultural economy. Poland is also one of the countries included in an on-going interdisciplinary and international research effort to investigate the impacts of climate change on the international sour cherry industry (Winkler et al. 2010, 2013b).

\section{Data and methods}

Daily minimum air temperatures from 184 synoptic and climatological stations situated within Poland were employed in the analysis. The period of record is 1951-2010 for the majority of stations, although stations with shorter record lengths were also included, particularly in areas with complex relief and environmental conditions, to improve coverage. The analysis was limited to late spring, defined as April, May and June. A freeze event was defined as a minimum temperature below $0^{\circ} \mathrm{C}$.

Three different circulation classifications were considered, given the different methods used in their development. The Lityński classification (LIT; Lityński 1969), which was created specifically for Poland, uses zonal and meridional circulation indices as well as sea-level pressure, with each index divided into three equally probable classes. The Niedźwiedź classification scheme (NIE; Niedźwiedź 1981), which is based on air mass advection and type of baric system, was also used. That classification was initially created for Southern Poland and then was extended to other regions of the country. The third scheme was the Grosswetterlagen classification (GWL), available for Central Europe. It is based on work by Hess and Brezowsky on large-scale weather systems with a focus on the direction of air mass advection and location of pressure systems (Werner, Gerstengarbe 2010). A detailed description of the types of circulation for each of the three calendars is provided in the works cited, and a 
summary of the circulation types for each of the three schemes is provided in Ustrnul and Czekierda (2009). The frequency of occurrence of last spring freeze was linked to the different circulation types for the three classification schemes. In addition, the conditional probability of all freeze events in May and June was estimated for each of the circulation types.

\section{Results}

\section{Climatology of last spring freezes over Poland}

Last spring freezes in Poland occur on average between the middle of April along the coast and the last week of May in mountainous areas below 1,000 $\mathrm{m}$ a.s.l. (Fig. 1). This map should be interpreted cautiously, however, as local relief has a large influence on minimum temperature, with landscape depressions having a higher probability of cold air drainage and cold air pools that can lead to freeze events. Such situations can occur in the large structural basins and mountain valleys of southern Poland, as well as in small depressions in other regions of Poland, especially in the north, where the terrain can also be complex. The spatial density of the observing stations limits the ability to detect the influence of local relief on minimum temperature.

The distribution of the dates of last spring freeze are skewed, as can be seen from the large difference between the average date and the lat-

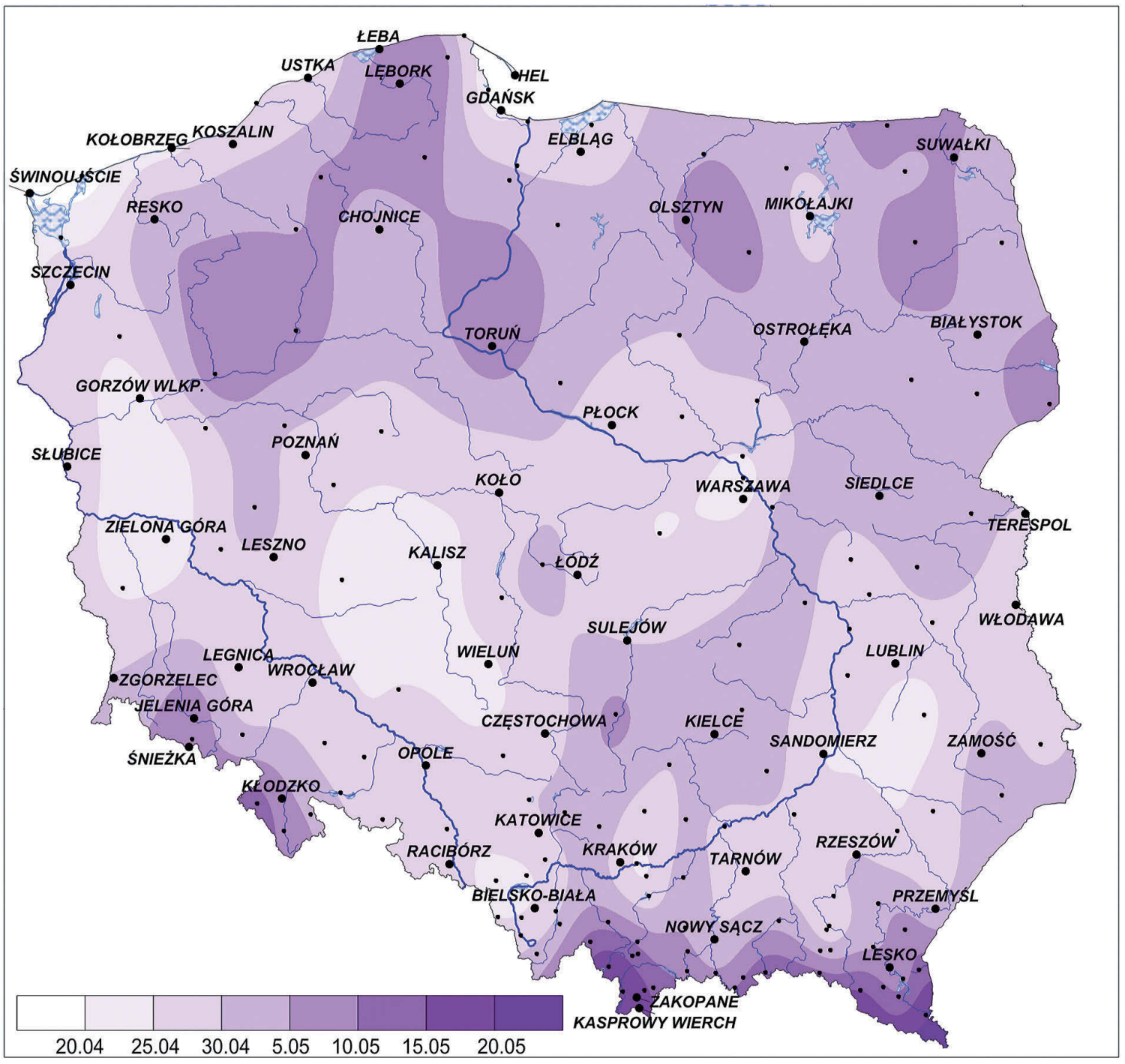

Fig. 1. Average date (day.month) of last spring freeze 

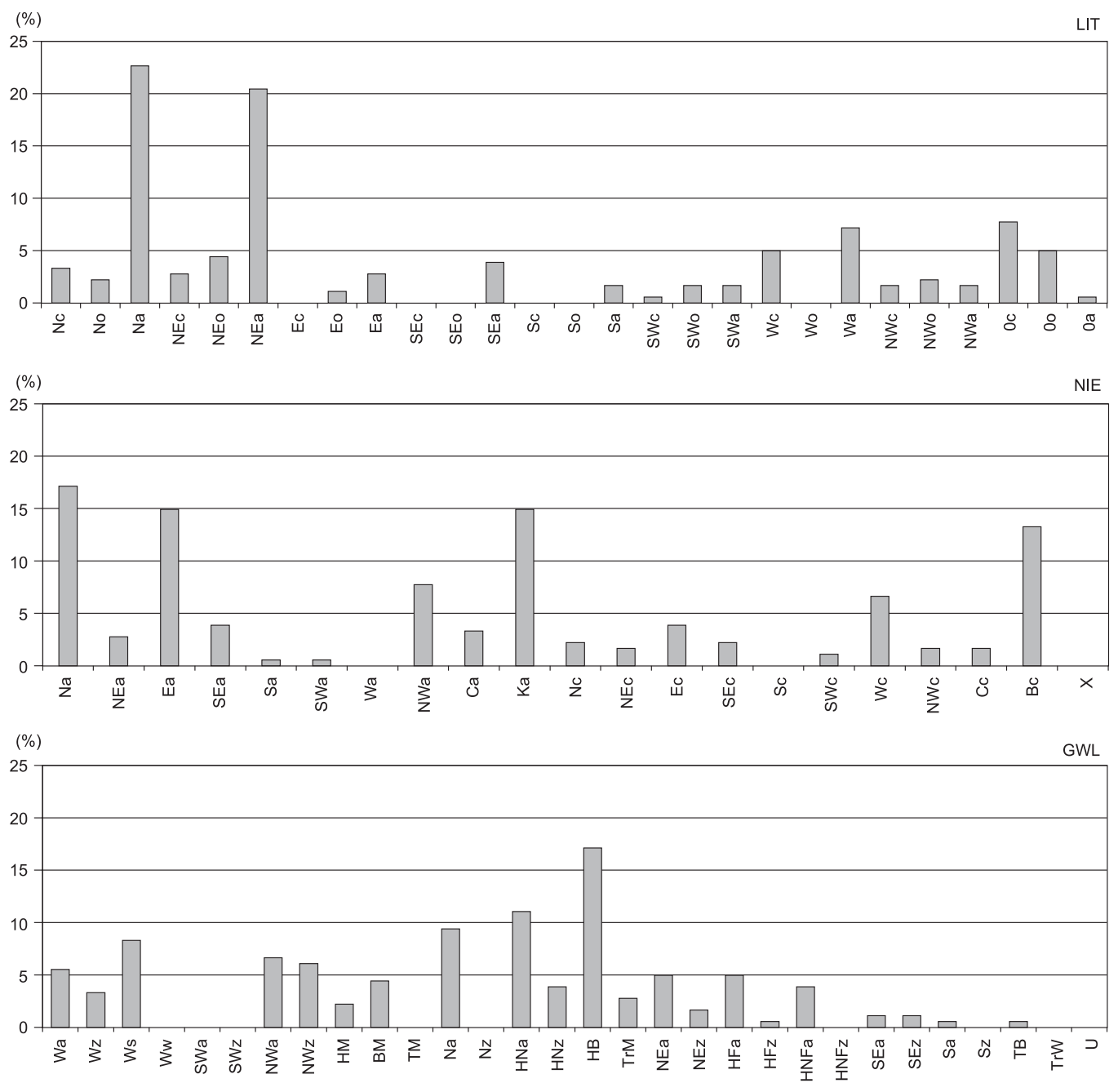

Fig. 2. Frequency of the latest spring freezes by circulation type

est freeze dates shown in Table 1. For seven of the study years, the latest freeze date in Poland occurred toward the middle or end of June.

\section{Circulation types and last spring freeze}

For each year and station, the last day with a freeze event was ascribed to the circulation type, for each of the three classifications, that occurred on that day. As seen in Figure 2, the last spring freeze was associated with many circulation types, however the significant freeze frequency can be noticed only for a small number of synoptic situations. For the Lityński classification, half of the last spring freezes, when summed across stations and years, occurred with circulation types $\mathrm{Na}$ (northerly anticyclonic) and NEa (north-easterly anticyclonic). Between $5-10 \%$ of the station/ year combinations experienced last spring frost with circulation types Wa (westerly anticyclonic) and 0c (neutral cyclonic, low centre). Last spring freeze occurred infrequently with the other $\mathrm{Li}$ tyński circulation types. For the Niedźwiedź classification, almost $70 \%$ of the cases occurred with circulation types Na (northerly anticyclonic), Ea (easterly anticyclonic), Ka (anticyclonic wedge or ridge of high pressure), or Bc (cyclonic through). For both classification schemes, last spring freezes primarily were associated with anticyclones and advection from the north and northeast or with a surface high pressure wedge over Poland. An exception is the Niedźwiedź Bc type, which is characterized by a low-level cyclonic trough following a frontal passage, although advection from the north also occurs with this circulation type. An analysis of the detailed weather conditions during the freeze occurrences associated with these classification types showed cloud- 
less nights in almost every single case. The GWL classification does not explain the influence of circulation as unambiguously as the other two classifications. Six of the GWL circulation types were associated with at least 10 cases of last spring freeze, although the largest number of freeze events (over 30) occurred when a surface high pressure was situated over the British Isles, with northerly advection over Poland (HB type). Simultaneously, the number of particular GWL types occurrence were relatively small and some results can not be correctly interpreted from the statistical point of view.

The latest spring freeze at a station is associated with the four Lityński (Fig. 3) and four Niedźwiedź (Fig. 4) circulation types. These circulation types are responsible for freeze events
Table 1. The latest spring freezes recorded in Poland (1951-2010) and the associated circulation types

\begin{tabular}{|c|c|c|c|c|}
\hline Date & Stations & NIE & GWL & LIT \\
\hline 30.06 .1962 & Komańcza & $\mathrm{NWa}$ & $\mathrm{NWz}$ & $\mathrm{Nc}$ \\
\hline 27.06.1957 & Poronin & $\mathrm{Na}$ & $\mathrm{HM}$ & $\mathrm{Na}$ \\
\hline \multirow{3}{*}{ 25.06.1994 } & Olewin & \multirow{3}{*}{$\mathrm{Ca}$} & \multirow{3}{*}{$\mathrm{BM}$} & \multirow{3}{*}{ SWa } \\
\hline & Jabłonka & & & \\
\hline & Stuposiany & & & \\
\hline 23.06.1959 & Lębork & $\mathrm{Ea}$ & $\mathrm{HFa}$ & $\mathrm{NEa}$ \\
\hline 20.06.1959 & Biebrza & $\mathrm{Bc}$ & $\mathrm{HB}$ & $\mathrm{Na}$ \\
\hline 19.06.1978 & Słoszów & $\mathrm{Ka}$ & $\mathrm{BM}$ & $\mathrm{Na}$ \\
\hline 15.06.1966 & Opole Lubelskie & Ec & $\mathrm{HFz}$ & SEa \\
\hline \multirow{3}{*}{ 15.06.1967 } & Zawoja & \multirow{3}{*}{$\mathrm{Cc}$} & \multirow{3}{*}{$\mathrm{NEz}$} & \multirow{3}{*}{ NE0 } \\
\hline & Sieniawa & & & \\
\hline & Witów & & & \\
\hline
\end{tabular}

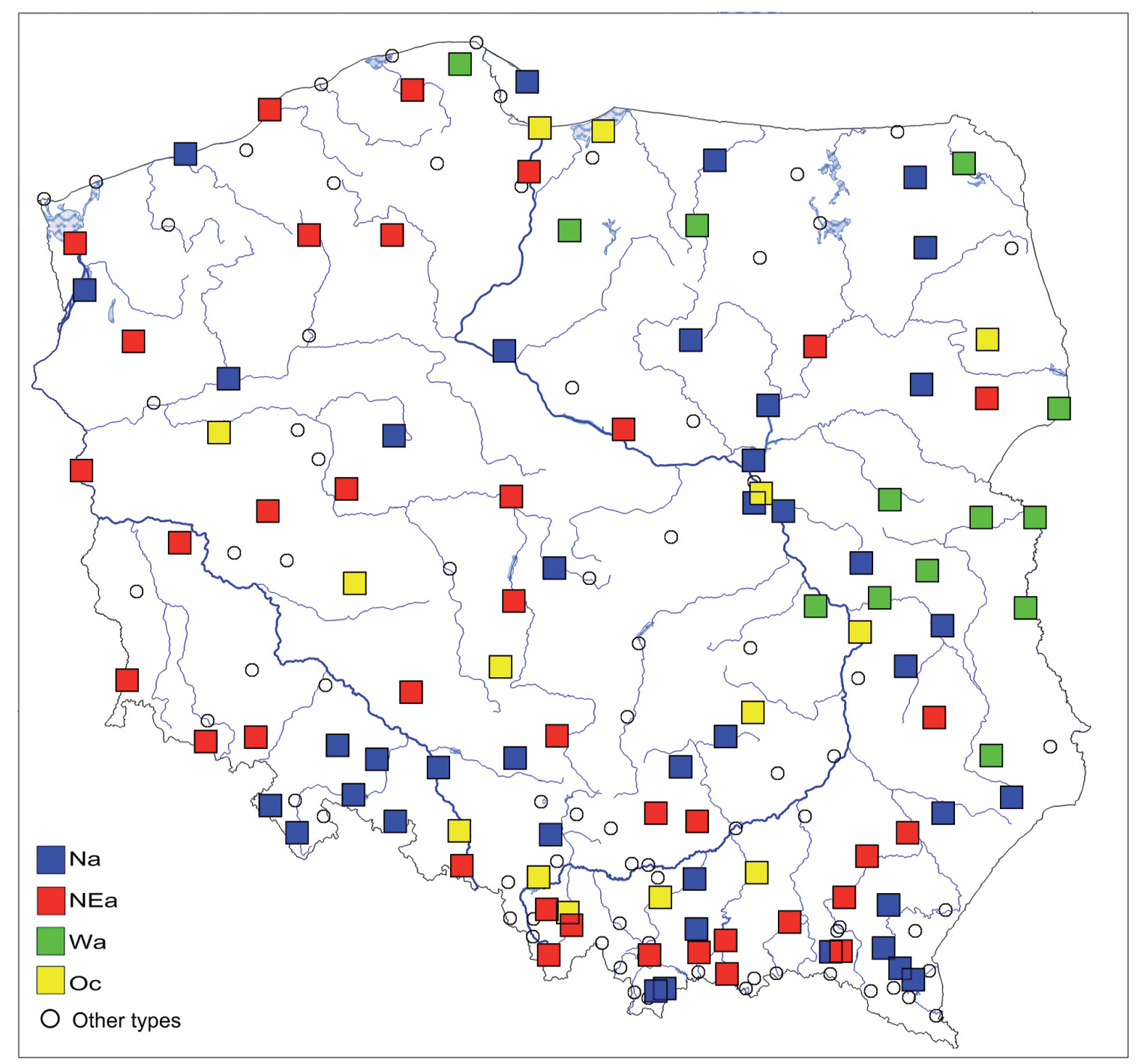

Fig. 3. Spatial distribution of circulation types responsible for the latest spring freezes (according to the Lityński classification) 


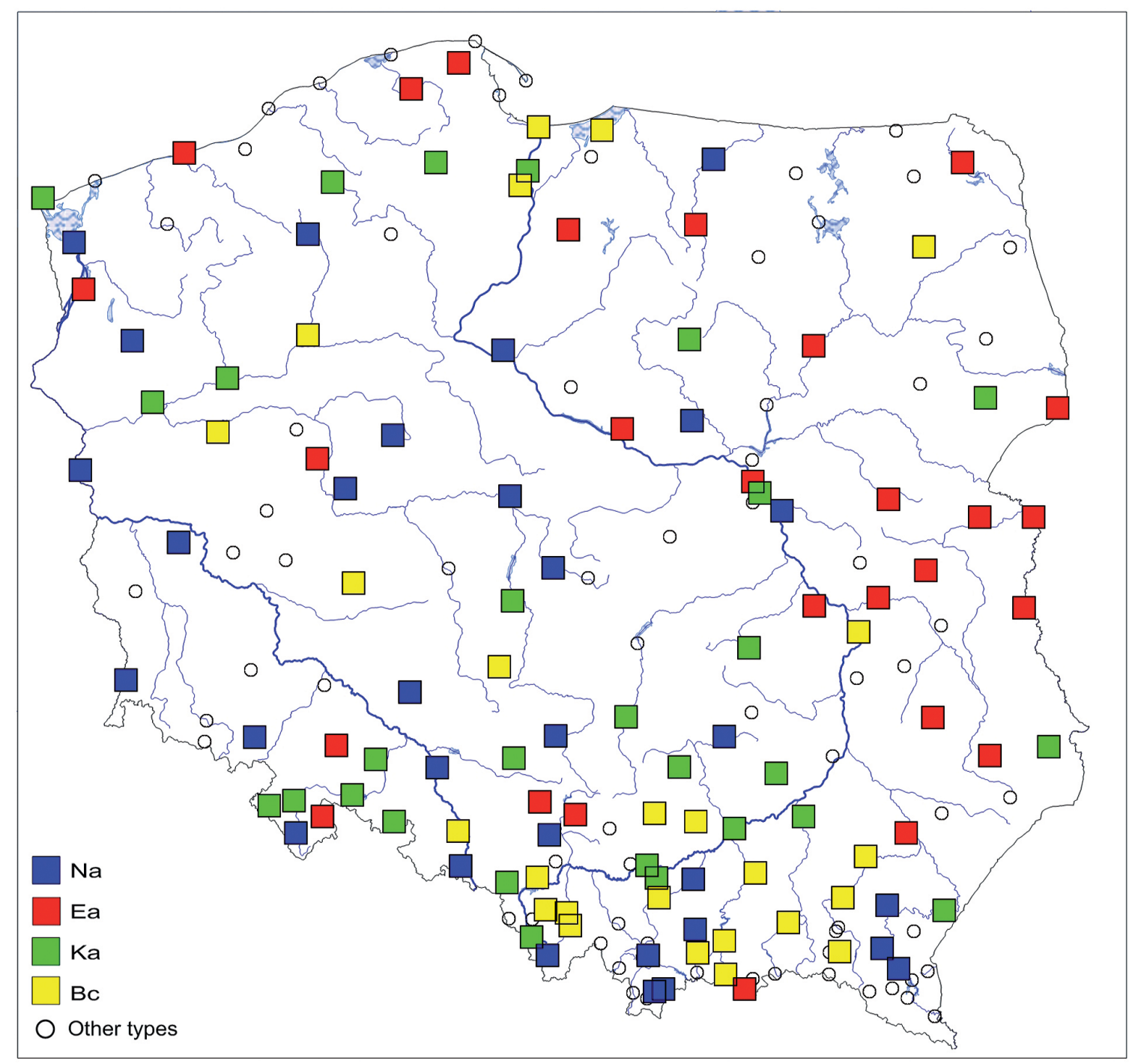

Fig. 4. Spatial distribution of circulation types responsible for the latest spring freezes (according to the Niedźwiedź classification)

across all of Poland, although some spatial preferences are observed. For example, the Lityński Wa (westerly anticyclonic) type and the Niedźwiedź Ea (easterly anticyclonic) type are mostly confined to the latest spring freezes in the eastern portion of Poland.

\section{Freeze occurrence probability}

As the flower buds of perennial trees lose hardiness, the probability that a freeze event will cause damage increases. Thus, freeze events that occur later in spring and early summer are a greater threat to perennial crops than those that occur earlier in the spring season. To investigate this further, the probability of a freeze event in May and June was estimated conditional on the circulation type from the Lityński and Niedźwiedź classifications. GWL classification was not taken into account due to the statistical problem mentioned above. This analysis differs from the analyses above in that all May and June freeze events are considered, whereas the earlier analyses focused on only the last spring freeze event of each year. To help ensure that inhomogeneities in the temperature records are not influencing the results, a freeze event needed to be recorded on at least 2 stations to be included (regardless the horizontal distance between the stations). Conditional probability takes into account both the frequency of the particular circulation types and the freeze events and should 

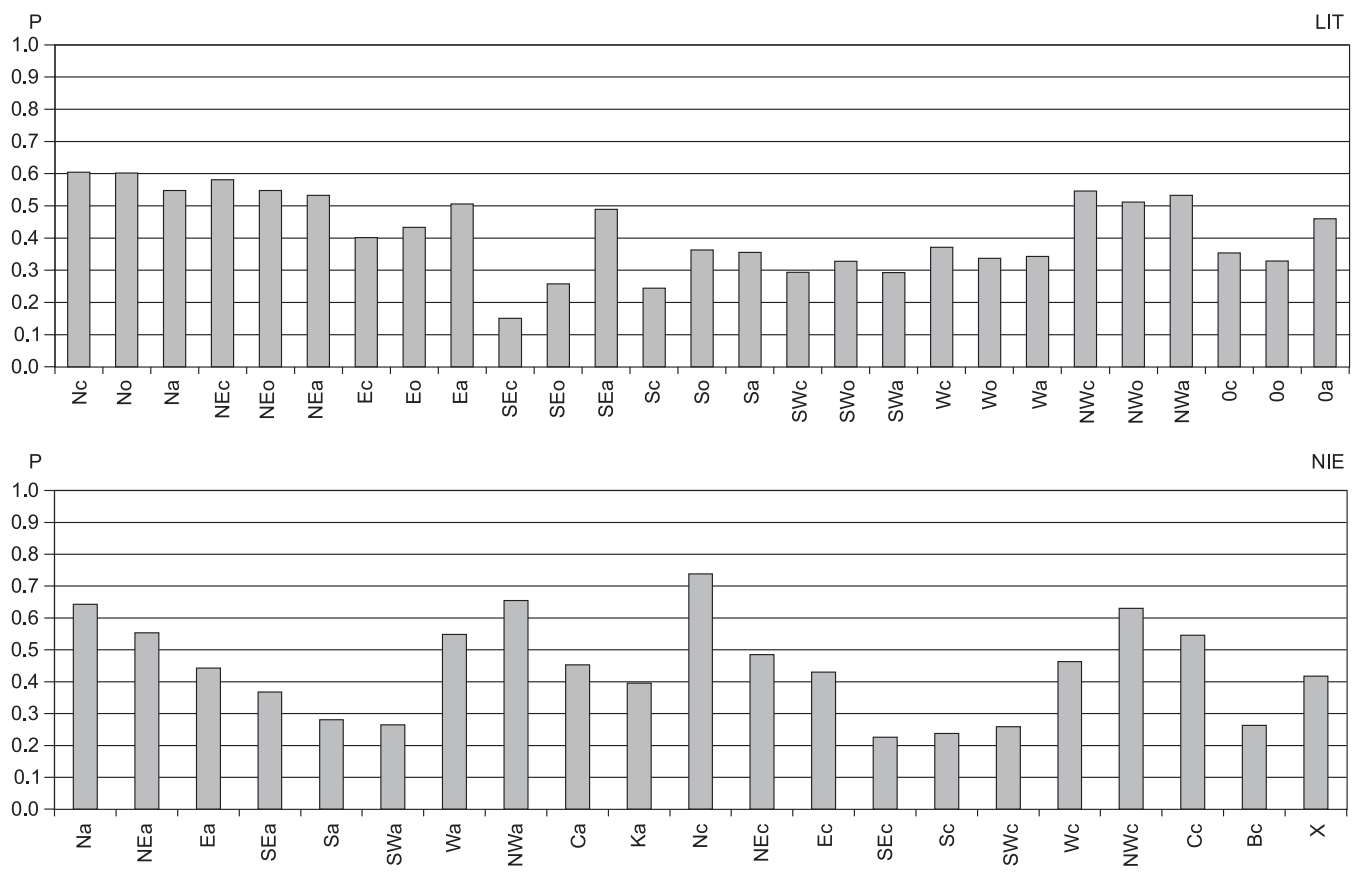

Fig. 5. Conditional probability of late spring freezes (May-June) by circulation type

not be confused with the frequency of freeze occurrences. The goal of this analysis is to identify those circulation types that pose the greatest risk to perennial crops.

For the LIT classification, the probability exceeds $50 \%$ for the types with air masses originating from the northern sector (Fig. 5), with the inferred advection of arctic air. The probability of a freeze in May and June is more than 30\% for the other LIT types, except for SEc, SEo, Sc (south-easterly cyclonic, south-easterly neutral, south cyclonic) where the probability is only 15$20 \%$. Larger differences in probability between circulations types are observed for the NIE classification. The highest probability is observed for northerly cyclonic type (Nc: 74\%). High probability is also seen with the northwesterly advection types. As excepted, the lowest probabilities, $20 \%$ or less, were associated with the NIE circulation types with southerly advection, particularly those with cyclonic airflow.

\section{Conclusions}

This article describes the influence of atmospheric circulation on the occurrence of spring freeze events in Poland. Three different classifications were used to represent the circulation.
They have been applied due to their different features: macroscale by Grosswetterlagen, an objective system for Poland by Lityński and one mesoscale system by Niedźwiedź. Despite the classification all of them show the similar general relationship between atmospheric circulation and late spring freezes. However, it is clearly seen that the best relationship between some types and late freezes can be found for the mesoscale Niedźwiedź classification. Just some types distinguished in this scheme reveal the highest frequency as well as conditional probability of these events.

The probability of late spring freezes, including the last freeze in a given year, is highest with northerly, and occasionally easterly, advection. Less frequently, spring freezes can occur with the northerly airflow following a cyclonic trough and frontal passage. These circulation types were responsible for spring freeze events across all of Poland, surprisingly with little regional preference for any of the circulation types.

The substantial differences in the conditional probability of late spring freeze events between the circulation types suggest that circulation classifications can be used to help understand the complex temporal trends in the freeze risk for perennial crops and how freeze risk might change in the future. 


\section{Acknowledgments}

This work was supported by the project: Towards an Integrated Framework for Climate Change Impact Assessments for International Market Systems with Long-Term Investments, National Science Foundation CNH Award No. 0909378. The authors also thank Ms. K. Pianko-Kluczyńska for providing the Lityński classification calendar.

\section{References}

Beck C., Philipp A., 2010. Evaluation and comparison of circulation type classifications for the European domain. Physics and Chemistry of the Earth 35: 374-387. DOI 10.1016/j.pce.2010.01.001.

Buishand T.A., Brandsma T., 1997. Comparison of circulation classification schemes for predicting temperature and precipitation in the Netherlands. International Journal of Climatology 17: 875-889.

Chmielewski F.M., Muller A., Bruns E., 2004. Climate changes and trends in phenology of fruit trees and field crops in Germany, 1961-2000. Agricultural and Forest Meteorology 121: 69-78. DOI 10.1016/S0168-1923(03)00161-8.

Chmielewski F.M., Rotzer T., 2001. Response of tree phenology to climate change across Europe. Agricultural and Forest Meteorology 108: 101-112, DOI 10.1016/S01681923(01)00233-7.

Eccel E., Rea R., Caffarra A., Crisci A, 2009. Risk of spring frost to apple production under future climate scenarios: the role of phenological acclimation. International Journal of Biometeorology 53: 273-286.

Huth R., Beck C., Philipp A., Demuzere M., Ustrnul Z., Cahynova M., Kysely J., Tveito O.E., 2008. Classifications of atmospheric circulation patterns: recent advances and applications. Annals of the New York Academy of Sciences. 1146: 105-152. DOI: $10.1196 /$ annals.1446.019.

Kaukoranta, T., Tahvonen R., Ylämäki A., 2010. Climatic potential and risks of apple growing by 2040. Agricultural and Food Science 19: 144-159. DOI $10.2137 / 145960610791542352$

Kreyling J., Thiel D., Simmnacher K., Willner E., Jentsch A., Beierkuhnlein C., 2012. Geographic origin and past climatic experience influence the response to late spring frost in four common grass species in central Europe. Ecography 35: 268-275. DOI 10.1111/j.16000587.2011.07173.x.

Lityński J., 1969. Numerical Classification of the Circulation and Weather Types for Poland, Prace PIHM 97: 3-14.

Moore G.W.K., Renfrew I.A., 2012. Cold European winters: interplay between the NAO and the East Atlantic mode. Atmos Sci Lett 13: 1-8. DOI: 10.1002/asl.356.

Niedźwiedź T., 1981. Synoptic situations and their influence on the spatial differentiation of selected climatic elements in the upper Vistula basin. Uniwersytet Jagielloński, Rozprawy habilitacyjne 58, Kraków.

Niedźwiedź T., 2000. Dynamics to selected extreme climatic events in Poland. Geographia Polonica 73: 2, 25-39.

Rigby J. R., Porporato A., 2008. Spring frost risk in a changing climate. Geophysical Research Letters 35m L12703. DOI 10.2478/v10117-012-0032-6.

Rochette P., Bélanger G., Castonguay Y., Bootsma A., Mongrain $D, 2004$. Climate change and winter damage to fruit trees in eastern Canada. Canadian Journal of Plant Sciences 84: 1113-1125. DOI 10.4141/P03-177.

Scheifinger H., Menzel A., Koch E., Peter C., 2003. Trends of spring time frost events and phenological dates in Central Europe. Theoretical and Applied Climatology 74: 41-51. DOI: $10.1007 /$ s00704-002-0704-6.

Ustrnul Z., Czekierda D., 2009. Atlas of extreme meteorological phenomena and synoptic situations in Poland. IMGW, Warszawa.

Ustrnul Z., Czekierda D., Wypych A., 2010. Extreme values of air temperature in Poland according to different atmospheric circulation classifications. Physics and Chemistry of the Earth 35: 429-436._DOI 10.1016/j.pce.2009.12.012.

Werner P.C., Gerstengarbe F-W., 2010. Katalog der Großwetterlagen Europas (1881-2009) nach Paul Hess und Helmut Brezowsky, 7. verbesserte und ergänzte Auflage. PIK Report No. 119.

Wibig J., 2001. The influence of atmospheric circulation on spatial distribution of air temperature and precipitation anomalies over Europe. Wyd. Uniwersytetu Łódzkiego, Łódź.

Winkler J.A., Thornsbury S, Artavio M., Chmielewski F.M., Kirschke D., Lee S., Liszewska M., Loveridge S., Tan P.N., Zhong S., Andresen J.A., Black J.R., Kurlus R., Nizalov D., Olynk N., Ustrnul Z., Zavalloni C., Bisanz J.M., Bujdosó G., Fusina L., Henniges Y., Hilsendegen P., Lar K., Malarzewski L., Moeller T., Murmylo R., Niedzwiedz T., Nizalova O., Prawiranata H., Rothwell N., van Ravensway J., von Witzke H., Woods M., 2010. Multi-regional climate change assessments for international market systems with long-term investments: A conceptual framework. Climatic Change 103: 445-470. DOI 10.1007/s10584009-9781-1.

Winkler J.A., Cinderich A.B., Ddumba S.D., Doubler D., Nikolic J., Perdinan, Pollyea A.M., Young D.R., Zavalloni C., 2013a. Understanding the Impacts of Climate on Perennial Crops. In: Pielke R.A. Sr. (ed), Climate Vulnerability: Understanding and Addressing Threats to Essential Resources, Volume 2: Vulnerability of Food Resources to Climate. Elsevier Inc., Academic Press: 37-49.

Winkler, J.A., Andresen J.A., Bisanz J., Guentchev G.S., Nugent J., Piromsopa K., Rothwell N., Zavalloni C., Clark J., Min H.K., Pollyea A., Prawiranta H., 2013b. Michigan's Tart Cherry Industry: Vulnerability to Climate Variability and Change In: Pryor S.C. (ed) Climate Change in the Midwest: Impacts, Risks, Vulnerability and Adaptation, Indiana University Press: 104-116.

Yarnal B., 1993. Synoptic climatology in environmental analysis. A primer, Belhaven Press, London and Florida, XV+195 pp.

Żmudzka E., 2004. The Climatic Background of Agricultural Production in Poland (1951-2000). Miscellanea Geographica 1: 127-137. 